\title{
Comprehensive Value Chain Development of Natural Resources for Economic Diversification: The Apiculture Approach
}

\author{
Akeem Abolade Oyerinde ${ }^{1 *}$, Theresa Ebia Omara-Achong2 \\ ${ }^{1}$ Department of Crop Protection, University of Abuja, Abuja, Nigeria \\ ${ }^{2}$ Raw Materials Research and Development Council, Abuja, Nigeria \\ Email: *akeem.oyerinde@uniabuja.edu.ng
}

How to cite this paper: Oyerinde, A.A. and Omara-Achong, T.E. (2021) Comprehensive Value Chain Development of Natural Resources for Economic Diversification: The Apiculture Approach. Advances in Entomology, 9, 59-69.

https://doi.org/10.4236/ae.2021.92006

Received: January 14, 2021

Accepted: February 27, 2021

Published: March 2, 2021

Copyright $\odot 2021$ by author(s) and Scientific Research Publishing Inc. This work is licensed under the Creative Commons Attribution International License (CC BY 4.0).

http://creativecommons.org/licenses/by/4.0/

\begin{abstract}
The present economic challenges in Nigeria call for a serious sustainable environment-friendly agricultural enterprise with a great potential that improves export earnings. It is our fervent believe that the contribution of the apiculture sector to its sustainable human development and specifically increases the income of beekeepers and traders of bee products through improved commercialization of quality bee products in Nigeria which will in turn lead to a drastic increase in the GDP of the nation. The overall goal of the Nigeria Apiculture Value Chain (AVC) Development Program is to contribute to an increase income of beekeepers and other actors on the AVC through increase in production capacity, stimulate the efficiency and competitiveness of the AVC products by improving standards, processing capacity so as to access higher value niche markets through Fairtrade International (FLO) certification or organic certifications and to achieve a total sales value of over $\$ 5$ million by 2035 (Sustainable Development Goal SDG) target on Food Security. Apiculture provides highly desirable products such as honey, comb/wax, pollen, propolis, bee venom, royal jelly, apilarnil and apilanil prop, value added products and pollination services. It is of note to stress the need to urgently embrace the use of modern techniques in keeping honeybees for industrial development of Nigeria and also to enhance exportation of the products to earn growth in the Nigeria's GDP by diversifying the monolithic economy that is presently based on crude oil exportation.
\end{abstract}

\section{Keywords}

Apiculture, Bee Products, Certification, Industry, Economic Diversification 


\section{Introduction}

Apiculture is an art that combines knowledge of habit and behaviour of bees, under varying environmental conditions, with the efficient manipulation of special equipment of the operator for man's economic benefit. It involves the use of modern techniques to keep honeybees for highly desirable products such as honey, comb/wax, pollen, propolis, bee venom, royal jelly, apilarnil and apilanil prop, other value-added products and pollination services [1].

Like all other agricultural endeavours, beekeeping is not only a noble and economically rewarding vocation, it is also a very viable economic pursuit undertaken all over the world [2]. It is, therefore, an important aspect of modern agriculture any developing economy would ignore to the detriment of its general wellbeing [2]. The potential that beekeeping offers to agriculture, in terms of providing raw materials for industrial development, employment, improved nutrition and income generation in developed, as well as, developing countries is substantial [1] [3].

This article focused on the assessment of the apicultural practice in Nigeria and provided options for the use of modern techniques in keeping honeybees to maximize production for local and international markets. This can be achieved through industrial development of the practice Nigeria and boost exportation of the products to earn growth in the Nigeria's GDP and in turn diversify the monolithic economy that is presently based on crude oil exportation.

\section{Beekeeping Practice in Africa}

Honeybee has been kept for its products in Africa for over 1000 years [4]. He further noted that, because beekeeping is associated with witchcraft in many East African countries, it was considered as old people's profession. Various tribes in Africa such as Mbere tribe of Tanzania, Wakamba or Pokat tribe of Kenya and Tiv people of Nigeria have a long record of bee rearing [5] [6]. Adejare guessed that these tribes must have been keeping bees for over one thousand years.

Africa has about $10 \%$ of the total world bees' population with the largest in Nigeria, Ethiopia and Egypt [7]. Although the origin of beekeeping in Nigeria is not certain, one of the earliest articles on the art, written by Lamb in 1927, claimed that Zaria (Zuma) people were probably the originators of beekeeping in Nigeria [2] [8] [9]. Beekeeping was practiced in different ways in Nigeria and in many cases the occupation is associated with some myths and folklore. For example, among the Tiv people beekeeping is believed to be a secret practice to which beginners must be initiated [9]. The practice always follows a varied and interesting pattern in different parts of the world. The natural nesting enclosures for bee habitation are cavities in the big trees, ant hills, rocks and disposed containers [7] [9]. Big trees with holes are few. The same goes for disposed containers, and hills and rock holes. The holes are invariably irregularly shaped therefore limiting the performance of the bees. Notable predators of bees like reptile (snake and lizard), as well as, amphibians (frog and toad) are rampant, reducing 
the labour force by feeding on them [1] [9] [10].

Consequently, an improvement was engendered by these problems which resulted in the development of improved beekeeping traditional methods. Hitherto, many traditional beekeepers in the tropical region used log hives, baskets, mud pots, gourds and other materials that cannot be opened for inspection of the colony. The traditional beekeeper hangs his hope of harvesting his crop on weather conditions. Harvesting honey from the natural and traditional hives entails access difficulties. The colonies are ruined in the attempt to reach honey and this is achieved with much difficulty. Such harvested honeycomb, when processed, gives impure honey even when undiluted [11]. Also, the bees and their young ones that should be preserved for future honey production are burnt in the harvesting process [7].

The history of modern beekeeping which involves the use of movable comb hives, dates to 1851, when an America apiarist, Lorenzo L. introduce it to the American apicultural industry. However, modern beekeeping practice is not popular in most part of Africa except Egypt, Kenya and Tanzania. This may be as a result of indulgence in the modern practice in these countries. In Nigeria modern beekeeping was initiated at the International Institute of Tropical Agriculture (IITA) farms at Ayepe and Ilesha in Osun state and Dogon Dawa, in Oyo state [7].

\section{Beekeeping Resources and Their Uses}

To the common man, it is very difficult to understand the real value of bees, beekeeping and honey production to economic development and diversification. The value of beekeeping could be described as sweet as honey itself, not minding other valuable value-added products and pollination service that sustains regeneration of crops/plants and sustainability of plant resources for human and industries.

The pollinating activity of honeybee is also of great value to food security, sustainability of industries with the provision of raw materials; as it is directly responsible for 80 percent insect pollination in plants [1] [2]. Example of crops benefiting from this pollinating activity ranges from food crops like cereal, pulses, and fruits to horticultural plants, as well as, tree plant.

The global demand for all bee products, cut across religious and cultural lines. Importantly, the domestic demand for beekeeper's honey in Nigeria remains amazing as, nearly every family is becoming interested in honey consumption; even at a high price provided the purity is guaranteed [6] [11] [12]. Also, the industries utilizing the bee products as raw materials are at present importing a large quantity of the products. This calls for urgent attention aimed at engaging in modern beekeeping to boost production for local and international markets.

Bee farming also provides people that take beekeeping as secondary occupation with extra source of income and nutrition. It sometimes generates foreign exchange earnings, thus it is seen lately and valued as a sustainable form of agri- 
culture. More so, the practice is not detrimental to the environment, since it helps in the regeneration of forest resource, reclamation of eroded land and pasture improvement.

The history of honey usage parallels that of man and in virtually every culture evidence can be found of its use as a food source and as a symbol employed in religious, magical and therapeutic ceremonies [12] [13] [14]. Recently, the nutritional advantages of honey over sugar syrup have been realized as it has proved to be better nutritionally and hence the global drift of interest towards honey consumption and industrial applications (Plate 1).

Health considerations and awareness are some of the driving motives behind increasing honey consumption. It is historically evident that honey has therapeutic and prophylactic use as it has been reported in the treatment of wounds, infections of the eyes and skin, as it acts as disinfectant and counteracts inflammation from time immemorial in the Babylonian and Egyptian empires [12]. In addition, to the curative ability of honey it is also a potential germ destroyer with renowned antiviral, antifungal, antiseptic and antibiotic activities, as well as, anti-inflammatory qualities.

Honey is considered a food only in a few societies such as those of the industrialized countries in Europe and North America, Latin America, North Africa, the Near East and increasingly in Japan. Of note is the introduction of over 40 new honey drinks in Japan [15]. In most parts of Africa, it is used for brewing honey beer and to a much lesser degree, as medicine; honey provides a valuable food when it is consumed in its unprocessed state, i.e. liquid, crystallized or in the comb. In these forms it is taken as medicine, eaten as food or incorporated as an ingredient in various food recipes [16]. Also, in addition to the thousands of "home-made" recipes in each cultural tradition, honey is largely used on a small scale, as well as, at an industrial level in baked products, cosmetics, confectionary, candy, marmalades, jams, spreads, breakfast cereals, beverages, milk products and many preserved products while in medicine, topical applications of honey under controlled conditions have shown accelerated wound healing in animals, treatment of burn and post-operative wounds in humans [17]-[22].

Beeswax from the honeybee has an extremely wide spectrum of useful applications and occupies a very special position among waxes. A report listed over

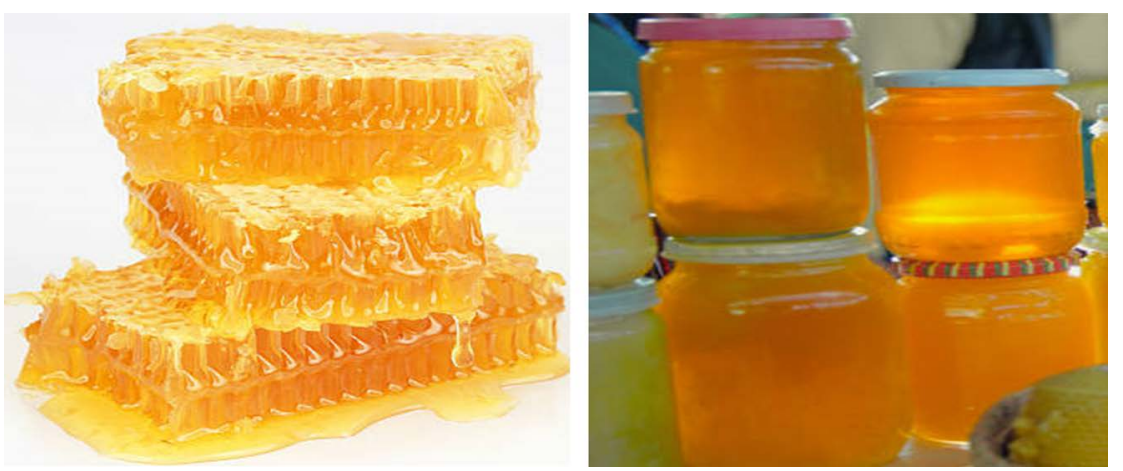

Plate 1. Honey. 
150 uses of beeswax [4]. Beeswax for centuries, before the advent of petroleum-based waxes, was appreciated as the best material for making candles. Ancient jewelers and artisans formed delicate objects casted in precious metals from beeswax. Furthermore, the colours of ancient wall paintings and icons containing beeswax are reported to have remained unchanged for more than 2000 years and the wrappings of Egyptian mummies for over 1000 years [23]. The beeswax has long found use in medical practice and the cosmetics industry, as they are used in compounding creams and lotions. Of all the primary bee products the beeswax has been, and remains, the most versatile and most widely used product (Plate 2).

In industrialized countries, the beeswax produced is used by beekeepers as foundation sheets. Approximately one third of the imported wax is used for cosmetics, one third for pharmaceutical preparations, one fifth for candles and the rest for other, minor uses [24]. While, in most developing countries where traditional beekeeping methods is common, wax is often wasted. Even when it is rendered, most of the beeswax product is subsequently exported.

This, however, depends very much on the local industry. Also, in the food processing industries beeswax has been used variously in the packaging and preservation processes. It has also been used as a separation agent in the confectionary industry and in cigarette filters [25]. A common, simple and small-scale application for beeswax is in the protection of containers against the effects of acids from fruit juices. Steel drums meant for storage and shipment of fruit juice and honey must be treated to prevent corrosion and iron dissolution. This treatment would have involved expensive food grade paint, or a plastic liner made from a food grade plastic film, but it is achievable with beeswax.

Beeswax is also useful in the preparation of a material for embedding or electrically insulating circuits of high and ultra-high frequency and highly effective in coating electrical material [25]. Common among other uses of beeswax include forming a small amount of various inks, pens, markers and even carbon paper. For agricultural pest control, beeswax has been an ingredient of slow release pellets of pyrethrin pesticides [26]. Waxing of the threads on water pipes was reported to prevent joints from corroding or locking and simultaneously made them waterproof.

It is also useful in the traditional textile industry for making batiks, while in
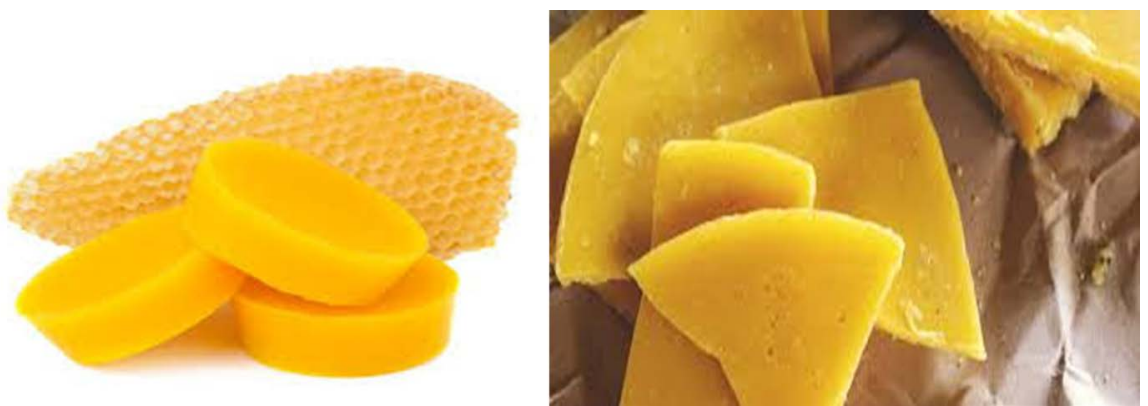

Plate 2. Beeswax. 
the pharmaceutical and medical lines it is used as a coating for drugs or pills, to facilitate ingestion but retards dissolution of the enclosed compounds until they reach the digestive tract. Beeswax can also be prepared as a mixture with various drugs and it functions as a time release mechanism, ensuring the release of the drug over a longer period. Sometimes beeswax alone serves as the carrier for the drug. Nalidixic acid suspended in beeswax also remained longer in the blood of tested animals after oral application than when the acid was administered directly [27]. In horticulture, a mixture of one part melted beeswax with one part of resin and enough lard or tallow to a pliable finely ground charcoal may be added to protect the wound against sunlight, is especially with grated surface on crops [14].

The royal jelly is another important product of beekeeping. It is secreted and fed directly to the queen or the larvae. The only situation in which royal jelly harvest becomes feasible is during queen rearing, when the larvae destined to become queen bees are supplied with abundant royal jelly (Plate 3). The hormonal effect of royal jelly is responsible for the enormous fertility of a queen genetically. An in vitro study has confirmed that $1 \mathrm{O}$-hydroxydecanoic acid in royal jelly has a thermo stable antibiotic activity which decreases with improper or long-term storage [28]. This has worked against Escherichia coli, Salmonella proteus, Bacillus subtilis and Staphylococcus aureus, Fungi and viruses also reported tumour growth inhibition in mice with prophylactic and therapeutic oral administration of royal jelly. Inhibition of rapid-growth cancers (leukaemia) was insignificant but inhibition was noticeable on slow-growing solid tumours [29]. The royal jelly promoted bone and skin lesions healing and anti-inflammatory action [28] [30].

Propolis is another major product obtainable from beekeeping. This product is useful in the extension of frozen fish storage life by 2 to 3 times. In Japan, the addition of only $30 \mathrm{ppm}$ of propolis to the rations of laying hens increased egg production, food conversion and hen weight by $6 \%$. Someone reported up to $20 \%$ additional weight gain for broiler chicken when $500 \mathrm{ppm}$ of propolis was added to their diet [31]. The use of propolis for post-harvest treatment and conservation of fruits was reported (Plate 4). The dermatological and cosmetic applications are probably the most common uses for propolis and its extracts. One of the most widely known and extensively tested properties of propolis is its antimicrobial activity. A positive synergistic effect has also been reported for propolis
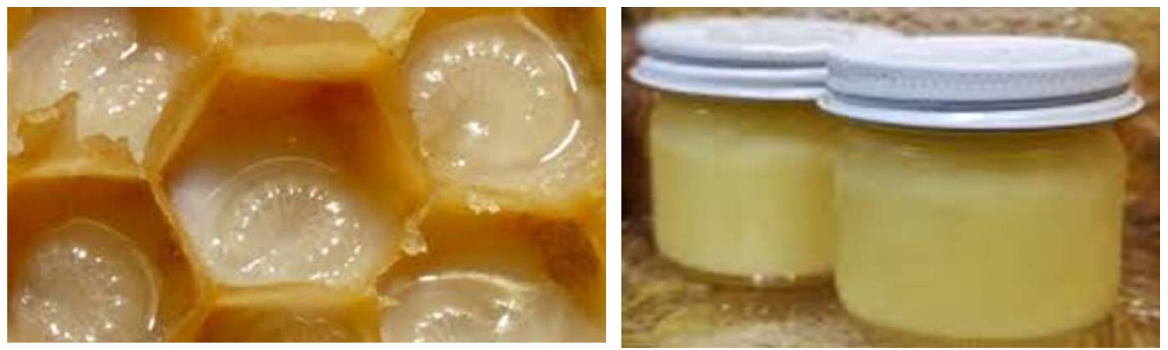

Plate 3. Royal Jelly. 
extract and various antibiotics. Sometimes, propolis extracts are more effective than commercially available drugs [31] [32].

Pollen is frequently described as the "only perfectly complete food". High performance recorded by athletes substituting on pollen are suggested as being informed by the "miracle food", just as the "busy bee" represents a role model for an active and productive member of society [14] [33]. Several decades of observations in Western European countries and a few clinical tests have shown pollen to be effective in treating prostate problems ranging from infections and swellings to cancer. There is also some evidence that ingested pollen can protect animals, as well as, humans from the adverse effects of $\mathrm{x}$-ray radiation [33].

The inclusion of pollen in the diets of domestic animals and laboratory insects resulted in the improvements of health, growth and food conversion rates. Chickens also exhibited improved food conversion efficiency with the addition of only $2.5 \%$ pollen to a balanced diet. Beekeepers also feed their colonies with pure pollen, pollen supplements or pollen substitutes during periods of limited natural pollen resource [12] [33] (Plate 5).

Bee venom therapy is very important in Apiteraphy i.e. use of bee stings in management of diseases. For instance, in the Republic of China, the use of bee venom therapy is combined with the knowledge of acupuncture by many hospitals, and the relief of some ailments are obtained by simply applying a bee sting or two to the affected area (Plate 6). This led to the formation of a society for api-acupuncture in Japan in 1980 [34] [35].

Bee venom has also been of benefit in treating many ailments. This therapeutic value was already known to many ancient civilizations. Today, the uses of bee venom are in human and veterinary medicine. Bee venom has long been used in traditional medicine for the treatment of various kinds of rheumatism. Although venoms of the different honeybee species differ slightly, there have been reports
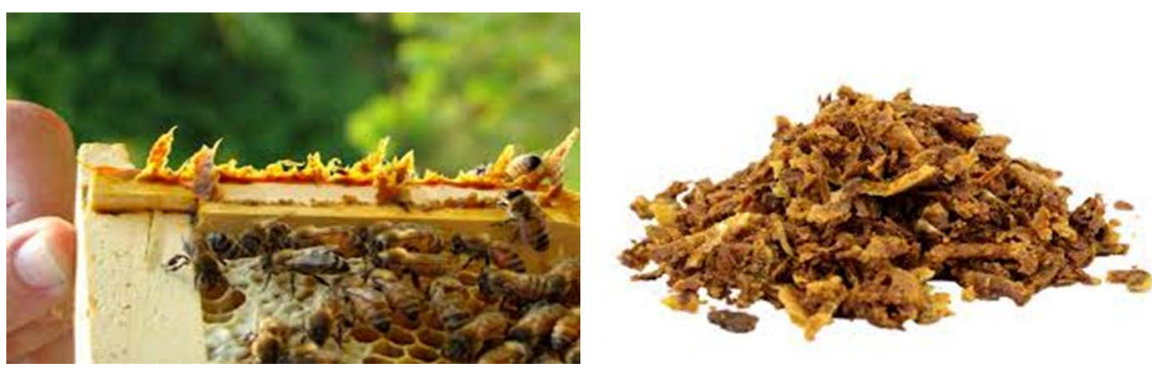

Plate 4. Propolis.
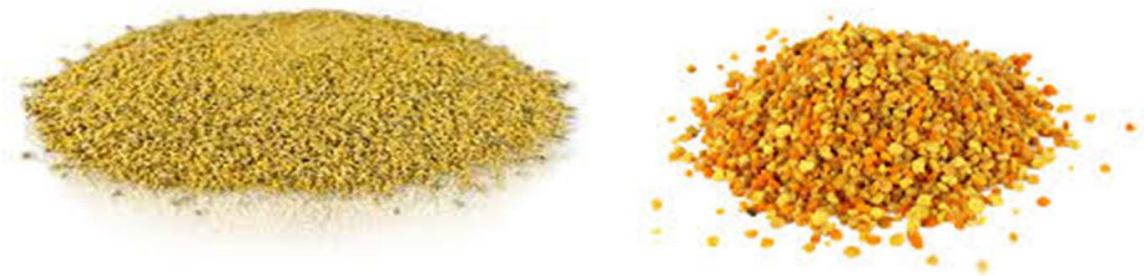

Plate 5. Pollen. 

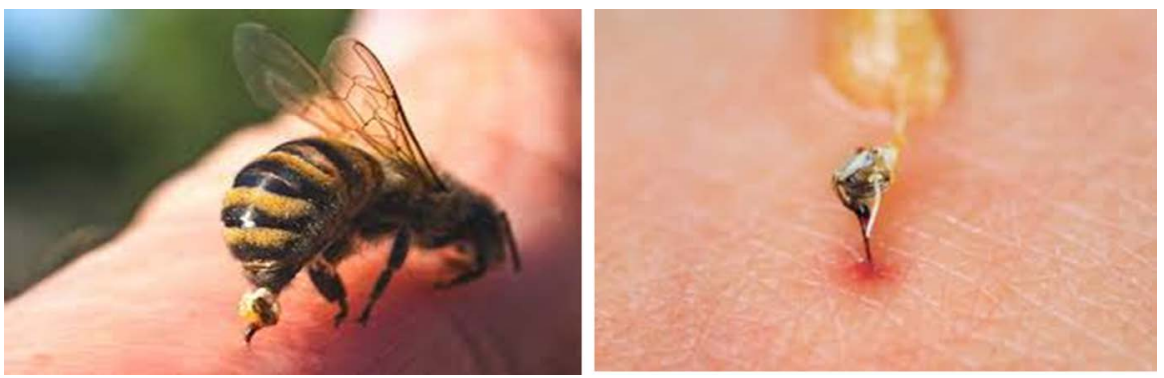

Plate 6. Bee Venom.
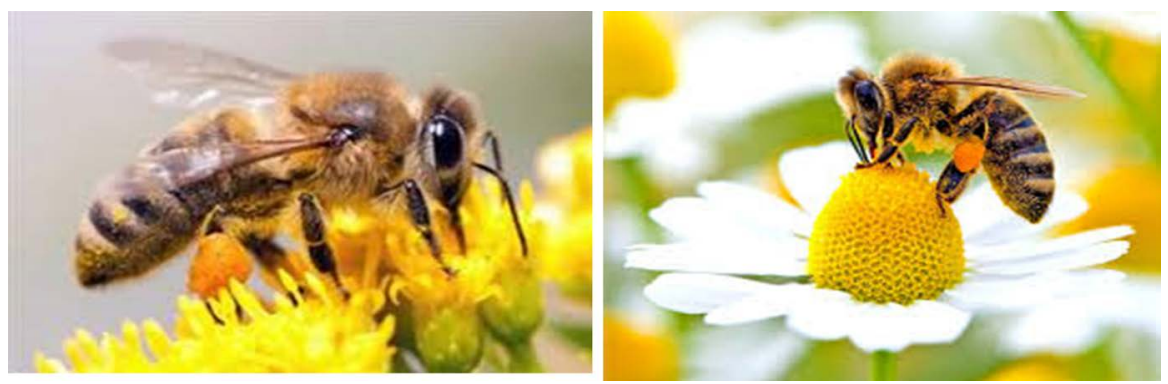

Plate 7. Bee Pollinating Plant.

of successful rheumatism treatment with Apis dorsata venom (Plate 7). Neurotoxic venom compounds have been potentially beneficial to epileptic patients. The protective value of bee venom and militating against the lethal or damaging effects of $\mathrm{x}$-rays has been investigated [36].

Notable among the relevance of bees is their crop pollinating activities (Plate 7) which is the major factor that maintains the existing floral heritage and enhances efficient crop production. Also, it could involve all interested member of the family and does not interfere with other farming activities.

\section{Nigerian Beekeeping Industry}

It is paradoxical that in certain areas of Nigeria that is seemingly ecologically disadvantaged for apicultural practice and where ideal housing and floral conditions are poor in dry season, beekeeping thrives impressively [2] [7]. Despite Nigeria still rates behind Ethiopia, Angola, Kenya, Tanzania, Egypt, Central African Republic, Madagascar, Morocco, Cameroon, Algeria, Chad, Burundi, Tunisia, Sierra Leone, Sudan, Libya, Mali, Guinea-Bissau, Mozambique, Uganda and Ghana in terms of honey production [12].

Recently in Nigeria, beekeeping awareness has made the practice popular in almost every part of the country. In some areas, men who have no hives, raid the colonies of bees in natural habitats when they are discovered. Despite the awareness, the larger proportion of the countries crude honey and other hive products comes from bee hunters, or at best traditional beekeepers. The age long practice of relying on getting bee products from bee hunters or traditional beekeepers is not only severely detrimental to the environment, but also compromises the quality of honey and the economic gains accruable. Other factors that 
may be militating against the improvement of beekeeping industry in Nigeria include bee pests and predators, human activities such as bush burning, use of pesticides and theft. Furthermore, apiculture is yet to be incorporated into the unified agricultural extension systems in Nigeria, thus creating a vacuum in the training of interested farmer.

\section{Prospects of Apiculture Value Chain in Nigeria}

The Nigerian beekeeping value chain development strategy is essentially three pronged:

1) It aims to stimulate competitiveness of the local apiculture industry as a means of increasing its participation in domestic, regional and global markets by building the processing and marketing capacity in the country;

2) It aims to increase honey and other hive products production volumes in the country by building the capacity of beekeepers especially in the area of queen rearing and hive management to produce higher volumes of quality honey on a consistent basis onto the local and international markets;

3) By strengthening co-ordination capacity in the value chain at National, States and Local Governments' stakeholders' forums and establishing formidable cooperative societies; dialogue and enhanced collaboration in the value chain this will go a long way to attract youth to the practice and in turn curb restiveness and hooliganism.

It is hopes that through this three pronged strategies it will be able to stimulate processing of honey and beeswax and other hive products domestically and therefore create more local value that could be easily exported as well as encourage producers to view beekeeping not only as sideline income stream, but a viable business that could yield substantial returns if managed viably.

The availability of more quality honey on the domestic market including increased processing capacity should stimulate the creation of more jobs domestically and result in increased revenue for the Nigerian economy and government. No doubt Nigeria is blessed with both flora and fauna suitable for organic beekeeping except that it seems there is an oversight on the part of the government to this goldmine that can give returns more than the petroleum industry as evident in Ethiopia where economic growth is based on beekeeping.

\section{Conclusion and Recommendations}

The assessment of the apicultural practice in Nigeria portrays the viability of use of modern techniques to maximize production of apicultural products and efficient development of the AVC in the country. This can be achieved through industrial development of the practice in Nigeria which will boost production of competitive products for local industry and exportation to international market. The earnings will diversify the source of income for the nation and lead to growth in the country's GDP and establish a shift from the present monolithic economy that is based on crude oil exportation. 


\section{Conflicts of Interest}

The authors declare no conflicts of interest regarding the publication of this paper.

\section{References}

[1] Ojeleye, B. (1999) Foundation of Beekeeping in the Tropics. CEBRAD Press, Ibadan, 1-225.

[2] Oyerinde, A.A. and Ande, A.T. (2006) A Preliminary Assessment of Modern Apicultural Practice in Kwara State, Nigeria. Journal of Agricultural Research and Development, 5, 203-214. https://doi.org/10.4314/jard.v5i2.42174

[3] Suberu, O.J., Ajala, O.A., Akande, M.O. and Olure-Bank, A. (2015) Diversification of the Nigerian Economy towards a Sustainable Growth and Economic Development. International Journal of Economics, Finance and Management Sciences, 3, 107-114.

[4] Adejare, S.O. (1990) Beekeeping in Africa. FAO Agricultural Series, Bulletin 68/6, Rome, $130 \mathrm{p}$.

[5] Mutsaers, M. (1991) Honeybees in Their Natural Environment in South Western Nigeria. The Nigerian Field, 56, 19-28.

[6] RMRDC (2018) Raw Materials Research and Development Council's Interventions in Beehive Products Development in Nigeria. Raw Materials Research and Development Council (RMRDC) Press, Abuja, 82 p.

[7] Hussein, M.H. (2000) Beekeeping in Africa Apiacta 1/2000. Pub. Apimindia International Federation of Beekeepers Association. 32-48.

[8] Taylor, J.E. (1978) Bibliography of Trop. APIC Part II, 18.

[9] Chinaka, C.C. (1995) Beekeeping Technologies for Nigerian Farmers. Extension Bulletin. Ahmadu Bello Univeristy, Zaria.

[10] Oyerinde, A.A. and Ande, A.T. (2009) Distribution and Impact of Honeybee Pests on Colony Development in Kwara State Nigeria. Journal of Agriculture and Social Science, 5, 85-88. https://doi.org/10.4314/jard.v5i2.42174

[11] Ande, A.T., Oyerinde, A.A., Adeyemi, V.I. and Job, O. (2010) Comparative Studies of the Physicochemical Properties of Honeys Produced from Various Units of the University of Ilorin Apiary. Agriculture and Biology Journal of North America, 1, 762-773. https://doi.org/10.5251/abjna.2010.1.5.762.773

[12] Olagunju, D. (2000) Alleviating Poverty through Beekeeping. Charli-Tonia Publisher, Osogbo, 1-189.

[13] Zwaenepoel, C. (1984) Honey: Facts and Folklore. Alberta Beekeepers' Association, Edmonton, $24 \mathrm{p}$.

[14] Crane, E. (1990) Bees and Beekeeping: Science, Practice and World Resources. Cornstock Publ., Ithaca, 593 p.

[15] PRC (1990) Japanese Honey Products, by Pacific Research Consulting Inc., (PRC), New Food Products in Japan, 15(1), 15(2) abd 15(3)m as cuted ub Katrabgem 1991.

[16] Olstrom, J.M. (1983) Dried Honey. The American Bee Journal, 123, 656-659.

[17] Cavanagh, D., Beazley, L. and Ostapowicz, F. (1970) Radical Operation for Carcinoma of the Vulva. A New Approach to Wound Healing. Journal of Obstetrics and Gynaecology, 77, 1037-1040. https://doi.org/10.1111/j.1471-0528.1970.tb03455.x

[18] Kandil, A., El-Banby, M., Abdel-Wahed, K., Abou Sehly, G. and Ezzat, N. (1987) 
Healing Effect of True Floral and False Number Floral Honey on Medical Wounds. Journal of Drug Research of Egypt, 17, 71-75.

[19] Kandil, A., El-Bandy, M., Abdel-Wahed, K., Abdel-Gawaad, M. and Fayez, M. (1987b) Curative Properties of True Floral and False Non-Floral Honeys on Induced Gastric Ulcers. Journal of Drug Research of Egypt, 17, 103-106.

[20] Kandil, A., El-Banby, M.A., Abdel-Wahed, K., Abdel-Gawaad, M. and Fayez, M. (1989) Curative Properties of Floral Honey and Honey from Sugar-Fed Bees on Induced Gastric Ulcers. Proceedings of the 4th International Conference on Apiculture in Tropical Climates, Cairo, 6-10 November 1988, 68-69.

[21] Efem, S.E.E. (1988) Clinical Observations on the Wound Healing Properties of Honey. British Journal of Surgery, 75, 679-681. https://doi.org/10.1002/bjs.1800750718

[22] Green, A.E. (1988) Wound Healing Properties of Honey. British Journal of Surgery, 75, 1278. https://doi.org/10.1002/bjs. 1800751236

[23] Benson, G.G., Hemingway, S.R. and Leach, F.N. (1978) Composition of the Wrappings of an Ancient Egyptian Mummy. Journal of Pharmacy and Pharmacology, 30, 78. https://doi.org/10.1111/j.2042-7158.1978.tb10785.x

[24] ITC, UNCTAD/GATT (1978) The World Market for Beeswax: A High Value Product Requiring Little Investment. ITC Publications, Geneva, $105 \mathrm{p}$.

[25] Sanyal, S.K. and Roy, S.K. (1967) Low Temperature Behaviour of Temporary Corrosion Protectives. LABDEV: Journal of Science and Technology, 5, 216-220.

[26] Ahmed, S.M., Gupta, M.R. and Bhavanagary, M.M. (1976) Stabilization of Pyrethrins for Prolonged Residual Toxicity Part II. Development of New Formulations. Pyrethrum Post, 13, 119-121.

[27] El-Sabbagh, H.M., Abdel-Gawad, H.A. and El-Said, Y. (1988) Development and Characterization of an Oleaginous Suppository Base. Alexandria Journal of Pharmaceutical Science, 2, 80-83.

[28] Yatsunami, K. and Echigo, T. (1985) Antibacterial Activity of Royal Jelly. Bulletin of the Faculty of Agriculture, Tamagawa University, 25, 13-22.

[29] Tamura, T., Fujii, A. and Kubiyama, N. (1987) Antitumor Effects of Royal Jelly. Nippon, Yakurigaku-Zasshi, 89, 73-80. https://doi.org/10.1254/fpj.89.73

[30] Fujii, A., Kobayashi, S., Ishihama, S., Yamamoto, H. and Tamura, T. (1990) Augmentation of Wound Healing by Royal Jelly. The Japanese Journal of Pharmacology, 53, 331-337. https://doi.org/10.1254/jip.53.331

[31] Sangalli, A. (1990) La propoli. L'Ape Nostra Amica, 12, 16-25.

[32] Millet-Clerc, J., Michel, D., Simeray, J. and Chaumont, J.P. (1987) Preliminary Study of the Antifungal Properties of Propolis Compared with Some Commercial Products. Plantes Me' dicinales et Phytothe' rapie, 21, 3-7.

[33] Schmidt, J.O. and Buchmann, S.L. (1992) The Hive and the Honey Bee. Dadant and Sons, Hamilton, 927-988.

[34] Ohta, N. (1983) Experiences with Api-Acupuncture. Honeybee Science, 4, 21-24. https://doi.org/10.1016/0304-3975(83)90128-7

[35] Sagawa, M. (1983) Success and Failure in Api-Acupuncture. Honeybee Science, 4, 27-28.

[36] Ginsberg, N.J., Dauer, M. and Slotta, K.H. (1968) Melittin Used as a Protective Agent against X-Irradiation. Nature, 220, 1334. https://doi.org/10.1038/2201334a0 